\title{
Science fiction and science dis/trust: Thinking with Bruno Latour's Gaia and Liu Cixin's The Three-body Problem
}

\author{
Elizabeth de Freitas \\ Manchester Metropolitan University
}

\section{Sarah E. Truman \\ University of Melbourne}

\begin{abstract}
This article draws on the ideas of Bruno Latour to examine the nature of science dis/trust and denialism in times of crisis. We argue that Latour's image of science creates new demands on public trust, shifting the focus from 'trusting that a particular scientific claim is true' towards an engagement with Gaia (earth) where scientists encounter and form alliances with agencies alive with trickster motive. We use the science fiction novel Three body problem to explore the specific challenges to scientific authority within this relational ontology, under various climatic regimes. We show how the SF novel offers insights into Latour's proposal for science as a risky diplomacy in a metamorphic zone.
\end{abstract}

\section{Introduction}

The Three-Body Problem is a Hugo Award winning work of science fiction by Cixin Liu, first published in Mandarin in 2006 and translated into English in 2014. The story opens in a "struggle session" in 1967, where physicist Ye Zhetai is interrogated in front of a cheering audience of Red Union revolutionaries during China's Cultural Revolution, for the crime of teaching relativity theory in a physics course. When he claims that relativity theory is a fundamental theory of physics, his young interrogators respond:

\footnotetext{
You lie! ...Einstein is a reactionary academic authority. He would serve any master who dangled money in front of him. He even went to the American Imperialists and helped them build the atom bomb! To develop a revolutionary science, we must overthrow the black banner of capitalism represented by the theory of relativity! (Liu 2014, p. 14)
}

When other crimes are raised - crimes such as teaching the big bang theory and the Copenhagen interpretation of quantum mechanics - the physicist defends himself by explaining that these theories are in line with experimental results. The interrogators reply that only the correct philosophy of Marxism should guide scientific experiments. When Ye suggests that the revolutionaries have misunderstood Marxism, which seeks to understand nature through experience, he receives more beating. Ye is beaten to death as the crowd shouts "Down with all reactionary academic authorities!" This particular fictional scene references the 'struggle sessions' 
that occurred during the Chinese Cultural Revolution, when many Chinese academics committed suicide rather than face such torture (Meyers et al. 1995). The Three-Body Problem's opening scene underscores how antiscience stances are nothing new, particularly in totalitarian states.

Today, in the midst of re-emerging nationalisms, and advanced neoliberal agendas, we hear science-bashing statements and outright science denialism by the U.S. president and administration, various industry giants, as well as segments of the American population (Pittinsky 2015). Trust in the authority of science, despite it often being the engine of economic growth and medical advancement, has been eroded in the U.S. in the past fifty years (Blake 2015; Estes 2015). Public attitudes towards science in the U.S. have been tracked since 1974, using the large and somewhat nationally representative General Social Survey (National Opinion Research Center at the University of Chicago 2018), indicating that people who self-identify as politically conservative shifted their beliefs the most, from significant trust in science (during the post-war period) to diminished trust in recent years (Gauchat 2012).

While science dis/trust is frequently related to concerns with bias, elite conspiracy, and a history of institutional racism, this paper suggests that Latour's image of a new climatic regime in the form of a trickster earth, "Gaia," underscores the need to rethink dis/trust of science. STS scholars like Latour and Stengers insist on using Lovelock's term Gaia, not because they think the earth is a goddess in some classical sense, but precisely because the mythical source of the term troubles Western rational images of science and destabilizes assumptions about a passive planet controlled by humans. The mythic Gaia is a smart trickster, much like Krishna in India, and Coyote in North America, each of whom "makes this world" (Hyde 1998). This approach, we contend, complicates the issue of science distrust. Gaia is not a world where science uncovers meanings that were previously hidden, but a radically contingent world where science encounters and forms alliances with agencies alive with trickster motive. Latour's pursuit of an immanent and terrestrial science problematizes classic Western images of science; for Latour, science is one of our best pluralistic "engendering" systems at work in a "metamorphic zone" (Latour 2018).

We turn to the speculative fiction novel The Three-Body Problem throughout the paper, as it sheds considerable light on contemporary issues of climatic regime and dis/trust in science. The novel is situated in an apocalyptic 'end times' on the planet Trisolaris which triggers another 'end times' on Earth, repositioning human life within larger geologic (and inter-galactic) transformations. The book raises provocative questions about the tensions between ideology, religion, science, and computation, and shows how fear and anxiety are mobilized in a world where science is suspect.

\section{Denial and distrust}

Science denialism refers to practices typically arising after the scientific community has embraced the particular scientific claims in question. Denial of evolution has a long history but found increased popularity in the 1960s, and climate science denialism gained a strong foothold in the 1980s (Hansson 2017). Denial of relativity theory was prevalent in the West in the 1920s and 1930s. Today one can find ample elaboration of supposed counter examples to relativity theory on the website Conservapedia founded by 'young earth' fundamentalists, in about 2006, to counter the "liberal bias in Wikipedia." Hansson (2017) offers a list of common tactics of those who might be considered denialists which includes: cherry picked evidence that is anomalous or exceptional, misused quotes from scientific literature, fabricated fake controversies, and declared bias and conspiracy in science. 
Creationists have used these tactics in the U.S. to ensure that their version of the earth's genesis is taught alongside evolution in science courses. In their book Merchants of Doubt, Naomi Oreskes and Erik Conway argue that climate science deniers learned from the tobacco industry the tactic of manufacturing uncertainty (Oreskes and Conway 2010).

Denialists are also critical of the overreliance on esoteric mathematics incomprehensible to most (Oreskes 2019). And yet they often operate with the assumption that science, as a form of truth-telling, should only operate through absolute epistemic certainty. They refuse to recognize that science might operate as a provisional process open to minor corrections, as science studies scholars suggest. Oreskes (2019) accordingly suggests that denialists put unreasonable demands on data when they point to issues with temperature data prior to the invention of the thermometer.

Contemporary distrust in science is focused principally on what many deem controversial topics such as climate science, stem cell research, evolution, the Big Bang Theory, and nano-technology (Rutjens et al. 2017). Different motivations fuel each of these. For instance, concerns with genetic modification are not correlated to any one particular disposition towards science, but many studies show that political conservatism and endorsement of a free-market ideology can reliably predict skepticism in the anthropogenic causes of climate change (Lewandowsky and Oberauer 2016). Drummond and Fischoff (2017) found that distrust in science is strongly associated with religious and political affiliation and that further education does not necessarily alter these beliefs. In other words, a science course or two at college or high school will not necessarily increase one's trust in the authority of science but might in fact be used to further fuel distrust of science. Present day science educators are facing a difficult task in such situations, trained to honour student perspectives and be culturally sensitive, whilst aware that scientific evidence clearly indicates strong anthropogenic factors in climate change. The National Science Teachers Association (National Science Teaching Association, 2018) was forced to publish in 2018 an official statement for teachers, offering support and guidance on how to teach climate science in communities where students do not trust it.

\section{Scientific consensus}

Oreskes (2019) argues that the term "scientific consensus" is key for understanding current distrust towards science, and points to the influence of the Kuhnian project, showing how scientific paradigms emerged in science through both experimentation and consensus building (Kuhn 1962). According to Orestes (2019), Kuhn's assertion that paradigms might be incommensurable seems to set science adrift in a game-world without any access to a neutral physical universe that might be relied on when comparing the legitimacy or warranting of competing theories. Later STS work showed how scientific practice was situated in political contexts, emphasizing the intersectional issues regarding power, privilege, and access that often determine which scientific 'truths' circulate as the truth, and who has the right to conduct science and how - see, for instance, the early work of feminist philosophers of science Evelyn Fox Keller, Sandra Harding, Helen Longino. In this view, science is partial, situated, and continually contested (Tsing 2015; Danowski and Viveiros de Castro 2017). In related efforts, science studies continues to track contemporary eugenics movements and contemporary practices of screening for disabled or intersexed foetuses, shedding light on some of the racist, ableist, and sexist logics that can accompany scientific practices (Kafer 2013). And historical accounts that reveal evidence of a history of racism in science are increasingly known to the public through books such as Rebecca Skloot's best- seller The Immortal life of Henrietta Lacks (Skloot 2010), which outlines the racist practices of U.S. medical science in the 1950s, 
when the cervical cancer cells of a poor Black tobacco farmer named Henrietta Lacks fuelled an entire cell culture industry without her knowledge or compensation. In addition, significant work on the violence inflicted on Indigenous communities through the social sciences has been influential in challenging scholarship in academia (Tuhiwai-Smith 2012).

And yet, in a disturbing flip, this emphasis on the biased and racist nature of scientific truth is now mobilized by neoliberal alt-right conspiracists, who advocate for the free exchange of capital unconstrained by environmental and scientific concerns (Lewandowsky et al. 2013). Further, accounts that reveal scientific complicity in racism and other forms of violence are now cited by religious communities who claim that the scientific establishment is suppressing their dissenting views (Rutjens et al. 2017). Opponents of abortion capitalize on "ableist and eugenic history of the reproductive rights movement to present themselves as the better ally to disability movements" (Kafer 2013, p. 163). Climate-change deniers pounce on the language of consensus, ironically identifying themselves with the renegade science of Galileo and his fight against the theocratic establishment. Republican strategist Frank Luntz, intent on discrediting climate science, is empowered by science studies perspectives that have shown how scientists are historically and politically situated, marshalling consensus to serve their agenda (Latour, 2017). Against the aims of Latour and most science studies scholars, climate change deniers use this work to argue against the truth claims of scientists whose work curtails the movement of capital. They argue that science is a political game like any other, and that the winners will determine which scientific 'truths' are validated. Chris Mooney (2005) highlights how Luntz strategized the politicization of science in the United States' Republican Party through advising politicians to actively recruit experts who supported the party's agenda. We see here a resonance with dystopian fiction. SF and reality collide.

\section{Credentials and legitimacy}

Three-Body Problem speaks directly to these questions of distrust and denialism, weaving together local and global environmental concerns of the $20^{\text {th }}$ century, and tracking their impact on the earth's future. One of the key characters in The Three-Body Problem reads Rachel Carson's 1962 controversial Silent Spring, a book published in the U.S. about the ecological destruction writ large by pesticide-use (Carson 1962). The intertextual inclusion of Silent Spring into the novel is significant. Carson was not a formally trained scientist, except for her Bachelor's degree, and she was targeted by the pesticide industry and accused of practicing bad science. Nonetheless, the book had impact on everyday Americans who were seeing first-hand the effects of DDT on crops, insects and health (Lockwood 2012). Petrochemical companies and the government responded to Carson's book with vitriol and fear (Smith 2001). Government agencies such as the Department of Agriculture "mounted a frantic public relations campaign to denounce Carson"(Smith 2001, p. 734). The attacks on Carson did not merely focus on discrediting her scientific understanding, but also were ad hominem attacks based on Carson's gender, calling her science 'soft' or 'scientific journalism' and her tone 'hysteric.'

The multi-national chemical company Monsanto published a speculative fiction called The Desolate Year, in response to Carson, in 1963, as an attempt to reach the wider public (Monsanto 1962). The Desolate Year conceives of an apocalyptic future without pesticides when nature strangles human life, allowing insects to control the earth. The Desolate Year describes a U.S. invasion of insects where millions of bugs take back the earth. In The Desolate Year, the insects are not simply depicted as destructive, but rendered repulsive in descriptions of their behavior. Monsanto defended the science of pesticides using a speculative fiction with queer imagery of female insects reproducing themselves without male counterparts, to heighten the grotesque unnatural 
dystopia of a world without petrochemical intervention: "the insects bred and re-bred, cross-bred, and inbred"(Monsanto 1962, p. 6). The Desolate Year continues with disgust at the speculative insects' flagrant indifference to breeding conventions: "Some didn't breed at all or need to: females simply produced more females which gave birth to more hordes of females" (Monsanto 1962. p. 6).

\section{Chaotic climates}

After the opening struggle session described at the beginning of the paper, The Three-Body Problem jumps 40 years hence, set still in China, but now situated in the first decades of the $21^{\text {st }}$ century. A nano-technology engineer, Wang Miao, is summoned to join an emergency meeting, attended by scholars, specialists, international military and government representatives. Wang is shocked to be taken to "Battle Command Center" and surprised to be addressed as "comrade" in a discussion about "combat zones" and a "time of war." He finds himself in a conversation about a war that he did not know was occurring. He asks: "But where is this war? This is probably the most peaceful period in history" (Liu 2014). He is then told:

Yes, the entire history of mankind has been fortunate. From the Stone Age till now, no real crisis has occurred. We've been very lucky. But if it's all luck, then it has to end one day. Let me tell you: It's ended. (Liu 2014, p. 65)

Wang learns that the established scientific community is under attack by an unknown enemy, and that recent experiments in various particle accelerators across the earth have revealed a shocking fact - that the laws of physics are not invariant across time and space. A young female theoretical physicist commits suicide and leaves the following note:

All the evidence points to a single conclusion: Physics has never existed, and will never exist. I know what l'm doing is irresponsible. But I have no choice. (Liu 2014, p. 61)

In addition to various suicides, there are unprecedented crimes against academia, research institutions, explosions in labs, murders of Nobel laureates, protests against new technologies, etc. There are also more general cultural trends, in cinema for instance, that cultivate a desire to return to the pastoral life before science spoiled nature. Wang is unsure of who or what might be causing these incidents and trends. But polarized beliefs emerge along various fronts, as the characters begin to realize that the planet as a whole is under attack and scientific mistrust and denialism proliferates around the globe.

Members of the Frontiers of Science network, most of whom are social elites, introduce Wang the nano-engineer to a computer game called Three Body, which involves wearing a haptic feedback suit and a panoramic viewing helmet. The game world has three suns, and their transits seem impossible to predict, causing long chaotic periods likely to wipe out civilization. In each iteration of the game there are no patterns of sun-rise and sun-set, and an unpredictable chaos reigns. The challenge is to solve the climate crisis. The game world taps all of Western and Eastern science, with some disorder and refusal of history, so that marking historical time in the world of the Three Body game is just as challenging as developing a science. The game Three Body reinforces the divide between scientists and the socially elite, and the general public because so few people can understand or afford to play the game. Only scientists and the very wealthy have the time or scientific understanding to engage with the game fully, but it is through playing the game that they will, in turn, be invited into an elite society called the Trisolaran Earth Organization. 
The book's chapters move back and forth between Wang in the game-world and Wang in the real world. The chapters of the book focused on the game world are deeply descriptive of unusual landscapes and odd spatial arrangements. The feeling of these chapters is radically different from those written about the story's 'real world,' and the reader is taken into a far richer description of the physical environment, including buildings, artifacts, corporeal sensations, and various affects - fear, desolation, hope. The physical movement entailed in the game world is registered by the reader in different ways, in part because it operates according to different space-time relationality, and unexpected historical encounters.

The game is centered on the goal of developing a scientific theory that will predict climate change in a world where the fundamental laws of science don't seem to hold. Every game iteration involves efforts to predict whether there will be a period of habitable regularity, in which the rhythms of climate will be known (i.e. a summer that follows winter, and when, and how long, and how hot, etc.). There are tensions between those who aim to predict the future, using science and theory, and those who think these self-styled prophets are quacks and dangerous renegades to be burnt at the stake. The fact that the fundamental laws of physics are shown to not hold in all conditions drives much of the concerns in the game world.

In such a chaotic world, the only invariants are empty tautologies: "Other than Stable Eras, all times are Chaotic Eras"(Liu 2014, p. 96). This vapid refrain of absolute contingency offers no way forward for scientific method. There seems to be no pattern of solar behavior that is invariant in the game world. How can science work in such a world? How can physics exist? The suicide words of the young female physicist ring true. Without invariance, and a certain repetition and cycle of familiar patterns, there can be no science.

\section{Betrayal}

In Down to Earth, Latour asks that we recognize the strong links between 1980s deregulation and the systematic effort to deny the existence of climate change. He states:

The hypothesis is that we can understand nothing about the politics of the last 50 years if we do not put the question of climate change and its denial front and center. Without the idea that we have entered into a New Climatic Regime, we cannot understand the explosion of inequalities, the scope of deregulation, the critique of globalization, or, most importantly, the panicky desire to return to the old protections of the nation-state - a desire that is identified, quite inaccurately, with the "rise of populism." (Latour 2018, p. 2)

Latour's account describes how the current "cosmocolossus" was brought on by globalization steered by greedy corporate elites, with many of us happily in tow; but these same sorts have now realized that there is simply not enough earth to go around. The "elites" have grasped the fact that the stable relations that were exploited in the name of Modernism are not sustainable, and that "the Earth, too, would end up resisting" (Latour 2018, p. 17). Notably Latour is critical of those who dismiss localized efforts to resist globalization as being archaic, backward, and irrational (Latour 2018). He frames the problem in terms of flawed conceptions of the local and the global, shared by both sides: 
Notably, Latour uses the language of "betrayal" to describe and justify the beliefs of those who are now turning against scientific elites, and who abide by "alternative facts" and "alternative reality" (Latour 2018). He affirms that such people have been "betrayed" and hence they turn to alternative facts. Trust is a complex relation involving affective, cognitive, and practical facets; it often involves rational reflection, and an awareness of dependency networks (Faulkner and Simpson 2017). Trust in science as truth-telling, and trust in the possibility that science will eventually model and predict earthly processes, seems to rest on appeals to rational deliberation, but in this case, there is more at stake. When reliance (trust) is pronounced but then broken, feelings can move from disappointment to betrayal. According to Latour, the widespread "epistemological delirium" that characterizes denial of science must be understood as an effect of betrayal in being denied the globe that was promised in the name of Modernism (Latour 2018). Shifting the nature of trust in science involves new, complex, more-thanhuman dependency relations of the Anthropocene. This involves negotiating new terrestrial relationships (Kaiser and Thiele 2017), as one formulates a new kind of science (Stengers 2018).

Rather than define science only in terms of its capacity or aim to warrant truth claims, Latour's conceptualization of scientific practice expands a more inclusive 'realism' through acknowledging (often making visible to humans) the more-than-human power networks and agencies that compose "metamorphic matter." In this view, science populates the world with diverse agencies (gluons, amoebas, gravitational waves, etc.) or understands the world as populated by diverse agencies, according to an immanent ontology that is no less realist for being thoroughly situated. Science is an activity, according to Latour, that cultivates pluralism and diversity through increasing awareness of the agencies that make up the world; this process is not simply a new way of talking or "socially constructing" the world because such an understanding would re-center the human as the interpreter/maker of all things. Latour (2017) asserts that agentic powers are "a property of the world itself and not only a phenomenon of language about the world" (p. 69).

Latour is explicit - we must defend scientific inquiry in today's context, not as a unified field but as a pluralistic engendering practice. He is not defending science in the name of white Euro-exceptionalism, but rather as a particular material and worlding practice that aims to responsibly encounter the more-than-human. Science studies were never anti-science (as it was sometimes interpreted); rather they were affirming the political project of science. For Latour, science studies is not simply a critique of false claims to objectivity, nor driven only to disclose the relativism and ideological bias of scientific truth. Rather, he aims to show how science gains in realism through multiplying agency. This is not what he calls the pseudo-realism that purports to describe the actor (human or other) as intentionally moving about, while the context (earth or other) lies inert in the background. Latour's realism, like Karen Barad's (Barad 2007) agential realism, is deeply committed to a philosophy of immanence. And according to these two thinkers, it is this agential realism that science pursues and elaborates, with notable failures (too many to list). In other words, science, as it is practiced or as it should be practiced, is principally focused on creating opportunities or experiments that reveal nonhuman agency, and thereby making visible new forms of life. Such practice is attuned to the metamorphic zone of more-than-human becoming. Rather than treat matter as inert and passive, "scientists work by negotiating with nonhuman entities, and by entering into alliances with them" (Shaviro 2015).

In such an environment, the notion of trust demands new diplomatic approaches. In as much as Latour asks that we trust science, he also points to how the trickster earth Gaia is not to be trusted in some fundamental sense, insofar as an agentic and vibrant matter has its own agenda. We need to expand our trust horizons and enter into 
relations of risky diplomacy with alien agencies that populate the world. Latour's scientific practice aims to engender a world rich with intimate forces, suffused with affective power, teeming with competing desires, replete with tricks and surprises.

And yet, the European Moderns (and offspring) have for centuries inflicted apocalypse on others elsewhere in the name of science, as though they had a right to 'the' earth. Kathryn Yusoff states "Seeking to monumentalize Anthropocene history is an attempt to reclaim an 'innocence' around this geohistory ... To be included in the 'we' of the Anthropocene is to be silenced by a claim to universalism that fails to notice its subjugations..." (Yusoff 2018, p. 11-12). She directs our attention to the "inhuman trajectories" that have always fuelled geology and its technological extraction of material 'resources'. This is science as a massive colonialist endeavor, digging and mining and extracting to serve a particular group of humans (Povinelli 2016). There simply is no one humanity that suffers the Anthropocene, but, rather, a "multiple earth" (Latour 2017). As Chakrabarty (Chakrabarty 2012) points out:

There is no 'humanity' that can act as a self-aware agent. The fact that the crisis of climate change will be routed through all our 'anthropological differences' can only mean that, however anthropogenic the current global warming may be in its origins, there is no corresponding 'humanity' that in its oneness can act as a political agent. (p. 15)

\section{Colonialism and conquest}

Science fiction writings can function as a political gesture that co-produces who and what matters in the pastpresent-future, what counts as knowledge, and who counts as human (Truman 2019a). In recent years queer, feminist, Black, and Indigenous scholars have asserted the need to rupture homogenous speculative fiction narratives, attend to different futurities, and recognize the politics of speculation as a situated practice. Feminist new materialist scholars have focused on how speculative alter-worlding must involve the practice of conceiving of different world orders that challenge norms more fundamentally (Åsberg et al. 2015).

The Trisolarans in The Three-Body Problem modify a proton to create a micro-particle 'sophon', a portmanteau combination of Sophia/wisdom and on(t)/ology. The sophon is a particle-sized weaponized 'intelligent being' that has the wisdom of a supercomputer encased within it. A group of sophons are hyper-intelligent and can perform quantum entanglements with each other and communicate back to their alien inventors. The Trisolarans launch sophons at Earth with the explicit purpose of halting scientific development on Earth. Sophons interfere at an imperceptible scale in scientific experiments, and thereby undermine the replicability of the experimental method. Given that replicability is an absolutely essential aspect for establishing scientific truth, this undermines the validity of science in the novel's "real world'." By undermining terrestrial science, the Trisolaran civilization hopes that Earthlings will not be able to enter the next stage of technological advancement and will therefore be unable to defend Earth when they arrive and invade 400 years in the future.

The Trisolarans target the theoreticians and elite astrophysicists who delve into theoretical speculation about cosmological events like relativity and the big bang. In order to avoid being targeted, various characters shun the dangerous speculative realm of basic research and foundational theory and position themselves as "practice" and service oriented. Some want to avoid theoretical physics because "It's easy to make ideological mistakes in 
theory" (Liu 2014, p. 43). This theory/practice divide is shown to be wrapped up with class divisions in China, where being born into an intellectual family means that you can never be fully trusted as part of the people's revolution (Li \& Issacson, 2019).

We note that attacks on science frequently target highly speculative theories, precisely because speculative thought is a potentially ideological and world-building practice. Speculative thought is used across the sciences and the humanities as both a research methodology and method for thinking otherwise (de Freitas 2017). Speculative thought can be conceptualized as a worlding practice, where acts of thinking-otherwise are ontogenerative and involve a relinking of the actual and the virtual (Truman 2019b). Much speculative thought focuses on 'the future' or a futurity that haunts the present (Shaviro 2015). Critiques of who gets to speculate on what and whose storying practices 'world' the future are a significant part of current theories surrounding speculative fiction. Queer, Afro-futurist, and Indigenous futurist theorists have drawn attention to how the idea of 'the future' has been central to the creation and ongoing enforcement of Imperial control, settler colonization, and technological domination where some populations are always rendered futureless or left out of dominant imaginaries (Lothian 2018; Schalk 2018).

An ongoing theme of scientific elitism is threaded throughout Three-Body Problem. In one register, the game functions for the Earth Trisolaran Organization as a way to enlist humans to support the Trisolaran invasion. In another, the game is nearly impossible to comprehend for the average person, and so ensures that only social and scientific elites will become part of the Earth Trisolaran Organization. The game compels many characters in the "real world" of the novel to become invested in the Trisolaran cause. Through logging on and playing the game repeatedly they begin to align themselves with a post-human world-to-come (through a Trisolaran invasion). This kind of investment in the nonhuman often characterizes speculative thought in diverse fields. In The ThreeBody Problem the practice of this speculative worlding is very much reserved for the social and scientific elite (both on Earth and in the Trisolaran civilization).

Social reproduction, religious fanaticism, imperialism, and technological modernity are common themes that repeat themselves in the Euro-western lineage of what is now known as science fiction, and these themes shaped the genre throughout the mid 1900s (Rieder 2008). Scientific advancement in the book The Three-Body Problem both the science performed by the Trisolarans and scientific advancements on Earth - is entirely fuelled by imperialism. Much of the plot, despite centering on an imperialist invasion of Earth from an alien world, continues to privilege humans as the main actors in science, even at the galactic-scale - Trisolaran scientific ambitions are recognizably humanist, but their science is beyond the capacities of humans. In other words, the novel seems to ultimately affirm human exceptionalism, whilst playing up the limits of human science. This affirmation is linked to the particularities of Chinese SF, which we haven't space here to adequately address (Li and Isaacson 2019). Rather than a work of extro-science fiction, in which scientific endeavours actually abandon the Modernist agenda of science, this novel is squarely within the genre of science fiction (Meillassoux 2015).

\section{Model and prediction}

We share with McKenzie Wark (2017) a concern that Latour (2017) does not adequately consider how earth science today is a science of simulation, of mathematical model building, of inventive abstraction, and that climate science's predictive knowledge comes from this endeavour. For Wark (2017), Latour is incapable of dealing with simulations of totality, which cannot simply be banished: "Through the fates of worlds modeled in 
computation, we have in outline the likely fates of the actual one. No amount of agential complexity or empirical complication really disturbs that big picture" (n.p.). Wark wants to situate scientific labour within the larger totality of labour, rather than in the micro or nano interactions of an emergent political ecology. Still, there is political gain in advocating for a "system of engendering" that distributes the agency of humans across the system, and values dependency and genesis. In terms of trust, this is a situation defined by complex networks of dependency relations. The terrestrial becomes a political actor in its own right and refuses to be used as a resource (Latour 2018). As Hird and Yusoff suggest, this approach opens up new forms of attachment that are about recognizing new kinds of dependency, new kinds of trust and diplomacy in the shadow of white geology (Hird and Yusoff 2019).

In the novel, Liu uses a mixture of current (and past) well-established scientific theories, concepts, and conjectures (including the three-body problem itself), with other entirely invented theories, concepts and conjectures conceived through speculative thought. The gravitational problem of three-bodies in its classical sense, is dated to Newton's 1667 Principia, where he explored the relational movements of three massive bodies. The problem was of huge technical importance in the $18^{\text {th }}$ century, because of its relevance to navigation and orientation, as various colonial exploits spread across the earth. The problem has been studied by many mathematicians including two of the most famous, Euler and Lagrange. The French mathematician Henri Poincaré -known also for his work on global telecommunications, topology, and scientific intuition - showed that the problem cannot be proved using classical analysis due to the sensitivity of the system to initial conditions. In other words, there is no closed-form solution, and we must use numerical methods to capture the unique systemic relations in any given three-body situation. The problem has hence been considered unsolvable in the general case, although periodic solutions have increased predictive power (Liao and Li 2019).

In The Three-Body Problem, the solipsistic "lazy" mathematician, Wei Cheng, has been laboring away quietly on the famous three-body problem for a number of years. Wei Cheng builds on Monte Carlo methods and other computational methods popular today in the world of machine learning, emerging in the last century due to advancements in computing power and algorithmic invention. Wei Cheng develops an "evolutionary algorithm" to help make sense of any three-body system. Meanwhile in the game world of Three Body, entire armies of soldiers are made to act as binary decision agents, a bottom-up method that is not as much democratic (a king commands his soldiers to submit) as it is reductive and algorithmic. Although there is some predictive power achieved in the game world through this approach, ultimately this approach fails to solve the three-body problem.

The fact that these numerical methods fail in the game world highlights the limitations of current machine learning strategies in the study of complex behaviour. Numerical methods, like those of Wei Cheng, rely on extensive data mining rather than analytic models. These approaches are not powerful enough to win the three-body game in the novel, and, notably, neither are they adequate in the eyes of many Al scientists today who are rethinking the role of causal and symbolic reasoning in learning (Pearl 2019). But the false hope of the game characters reveals their naivety and echoes our own fantasy that brute computational methods and predictive analytics will conquer all chaotic systems. The fact that the problem is only partially 'solved' using alien advanced computing power and quantitative methods that are binary in nature, reminds us of the limits of our current methods.

\section{Final comments}


We close by suggesting that Latour's future Anthropocene science will have to become more attuned to this metamorphic zone of posthuman becoming, a shapeshifting transactional mixture that subsumes human agency, nonhuman life, and mathematical models. The best way to ensure a healthy dose of distrust while nonetheless trusting science, is to realize that this metamorphic agentic zone involves a complex more-than-human network of dependency relations, and thus demands a kind of risky diplomacy on the part of all agents. Diplomacy becomes a key modality here, because it offers a space of potential strategic betrayal and manoeuvre, when partisan interests must be exposed: "Betrayal is part of diplomacy because the displacement betrays those who have sent him or her precisely because he or she modifies their values ... they see that the official attachment is not the one to be ready to die for. So, betrayal is a necessity; it introduces a margin and a space to manoeuvre" (Latour 2015, p. 51). In other words, science is trustworthy insofar as it operates according to a risky diplomacy within the metamorphic zone and according to a philosophy of immanence (de Freitas, 2019). In living with the possibility of betrayal, and "staying with the trouble" as Haraway (2016) reminds us, we affirm the power of science to proliferate agencies in a pluralistic and potentially more inclusive future. A speculative fiction novel like The Three-body Problem helps us to grasp the deeply pluralist nature of science, not as the keeper of timeless truths and politically neutral practices, but as an evolving practice implicated in galactic material processes, colonial conquest, and changing conditions on earth.

\section{Acknowledgement}

This work was supported by the Social Sciences and Humanities Research Council Canada, under Grant 158381.

\section{References}

Åsberg, C., Thiele, K., and van der Tuin, I., 2015. Speculative before the turn: Reintroducing feminist materialist performativity. Cultural Studies Review, 21 (2), 145-172.

Barad, K., 2007. Meeting the universe halfway: Quantum physics and the entanglement of matter and meaning. London: Duke University Press.

Blake, A., 2015. Americans increasing distrust in science - and not just in climate change. The Washington Post.

Carson, R., 1962. Silent Spring. Cambridge, MA: The Riverside Press.

Chakrabarty, D., 2012. Postcolonial studies and the challenge of climate change. New Literary History, 43 (1), 118.

Danowski, D. and Viveiros de Castro, E., 2017. The ends of the world. Cambridge: Polity.

Drummond, C., and Fischhoff, B. 2017. Individuals with Greater Science Literacy and Education Have More Polarized Beliefs on Controversial Science Topics. Proceedings of the National Academy of Sciences 114 (36), 9587-92. 
Estes, M., 2015. Young Americans growing distrust of science. Harvard Political Review.

Faulkner, P. and Simpson, T., 2017. The philosophy of Trust. Oxford: Oxford University Press.

de Freitas, E., 2017. Nonhuman findings from the Laboratory of Speculative Sociology. The Minnesota Review, 88, 116-126.

de Freitas, E., 2019. Science studies and the metamorphic multiple earth: Bruno Latour's risky diplomacies. Cultural Studies-Critical Methodologies.

Gauchat, G., 2012. Politicization of Science in the Public Sphere. A Study of Public Trust in the United States, 1974 to 2010. American Sociological Review, 77 (2), 167-187.

Hansson, S., 2017. Science Denial as a Form of Pseudoscience. Studies in History and Philosophy of Science Part A, 63, 39-47.

Haraway, D., 2016. Staying with the trouble: Making Kin in the Chthulucene. Durham, NC: Duke University Press.

Hird, M. and Yusoff, K., 2019. Lines of shite: Microbial-mineral chatter in the Anthropocene. In R. Braidotti and S. Bignalle, eds. Posthuman Ecologies: Complexity and Process after Deleuze. New York, NY: Rowman \& Littlefield, 265-282.

Hyde, L., 1998. Trickster makes the world: Mischief, myth and art. Farrar, Strauss and Giroux.

Kafer, A., 2013. Feminist, queer, crip. Bloomington, Indiana: Indiana University Press.

Kaiser, B. and Thiele, K., 2017. Terrestrial. In: R. Braidotti and M. Hlavajova, eds. Posthuman Glossary. Bloomsbury Academic.

Kuhn, T., 1962. The structure of scientific revolutions. Chicago: Chicago University Press.

Latour, B. 2015. Diplomacy in the face of Gaia. Bruno Latour in Conversation with Heather Davis. In H. Davis and E. Turpin (Eds.) Art in the Anthropocene. Open Humanities Press, 43-65.

Latour, B., 2017. Facing Gaia: Eight Lectures on the New Climatic Regime. Oxford: Polity Press.

Latour, B., 2018. Down to Earth. Oxford: Polity Press.

Lewandowsky, S., Gignac, G.E., and Oberauer, K., 2013. The Role of Conspiracist Ideation and Worldviews in Predicting Rejection of Science. PLOS ONE, 8 (10), e75637.

Lewandowsky, S. and Oberauer, K., 2016. Motivated rejection of science. Current Directions in Psychological Science, 25, 217-222. 
Li, G. and Isaacson, N., 2019. China turns outward: On the literary significance of Liu Cixin's science fiction. Science-Fiction Studies.

Liao, S. and Li, X., 2019. On the periodic solutions of the three-body problem. National Science Review, 6 (6), 1070-1071.

Liu, C., 2014. The three-body problem. New York: Tor.

Lockwood, A., 2012. The affective legacy of Silent Spring. Environmental Humanities, 1, 123-140.

Lothian, A., 2018. Old futures: speculative fiction and queer possibility. New York: New York University Press.

Meillassoux, Q., 2015. Science fiction and extro-science fiction. University of Minnesota Press.

Meyers, J., Yeh, M., and Domes, J., 1995. Chinese politics: Documents and analysis: Volume IV: Fall of Hua-KuoFeng (1980) to the 12th Party Congress (1982). Columbia: University of South Carolina Press.

Monsanto, 1962. The Desolate Year. Monsanto Magazine, 10, 4-9.

Mooney, C., 2005. The Republican War on Science. New York: Basic Books.

National Opinion Research Center at the University of Chicago, 2018. US General Social Survey.

National Science Teaching Association, 2018. NSTA Position Statement on The Teaching of Climate Science. National Science Teaching Association.

Nature Editorial, 2017. Beware the anti-science label. Nature, 545, 133-134.

Oreskes, N. and Conway, E., 2010. Merchants of Doubt. London, UK: Bloomsbury Press.

Oreskes, N. 2019. Why Trust Science. Princeton NJ: Prinston University Press.

Pearl, J., 2019. The seven tools of causal inference, with reflections on machine learning. Communications of the Association for Computing Machinery, 62 (3), 54-60.

Pittinsky, T., 2015. America's crisis of faith in science. Science, 348, 511-512.

Povinelli, E., 2016. Geontologies: A Requiem to Late Liberalism. Durham, NC: Duke University Press.

Rieder, J., 2008. Colonialism and the emergence of science fiction. Middletown: Wesleyan University Press.

Rutjens, B., Sutton, R., and van der Lee, R., 2017. Not All Skepticism Is Equal: Exploring the Ideological Antecedents of Science Acceptance and Rejection. Personality and Social Psychology Bulletin, 44 (3), 384-405. 
Schalk, S., 2018. Bodyminds reimagined: (Dis)ability, race, and gender in Black women's speculative fiction. Durham, NC: Duke University Press.

Shaviro, S., 2015. Discognition. London: Repeater.

Skloot, R., 2010. The Immortal Life of Henrietta Lacks. New York: Crown Publishing.

Smith, M., 2001. 'Silence, Miss Carson!' Science, Gender, and the Reception of Silent Spring. Feminist Studies, 27 (3), 733-752.

Stengers, I., 2018. Another science is possible: A manifesto for slow science. Cambridge: Polity Press.

Truman, S.E., 2019a. Inhuman literacies and affective refusals: Thinking with Sylvia Wynter and secondary school English. Curriculum Inquiry, 49 (1), 110-128.

Truman, S.E., 2019b. SF! Haraway's Situated Feminisms and Speculative Fabulations in English Class. Studies in Philosophy and Education, 38 (1).

Tsing, A., 2015. The mushroom at the end of the world: On the possibility of life in capitalist ruins. Princeton, NJ: Princeton University Press.

Tuhiwai-Smith, L., 2012. Decolonizing methodologies: Research and Indigenous peoples. 2nd ed. Zed Books.

Wark, M., 2017. Bruno Latour: Occupy Earth. Verso Blog.

Yusoff, K., 2018. A billion black anthropocenes or none. [Kindle Edition]. Available from Amazon.co.uk.

\section{Cite this Essay}

de Freitas, Elizabeth and Sarah E. Truman. "Science fiction and science dis/trust: Thinking with Bruno Latour's Gaia and Liu Cixin's The Three-body Problem." Rhizomes: Cultural Studies in Emerging Knowledge, no. 36, 2020, doi:10.20415/rhiz/036.e02 